\title{
Assessing Conformity with Generally Accepted Accounting Principles Using Expert Accounting Witness Evidence and the Conceptual Framework
}

\section{Russell Craig, Wally Smieliauskas, Joel Amernic}

In observations that are as relevant today as when published in 2007, McGregor and Street (2007: 46) highlighted the need for the IASB [International Accounting Standards Board] and FASB [Financial Accounting Standards Board] to resolve the 'controversial issue ...[of]... the status of the [conceptual] framework in the GAAP [Generally Accepted Accounting Principles] hierarchy.' They contrasted the generally higher status of the Conceptual Framework in 'the IASB's (as well as Australian, NZ, and Canadian) jurisdictions' with 'the framework's insignificant status at the bottom of the current US GAAP hierarchy' (p.46). They attributed the lower status in the U.S. 'to some [persons preferring] to retain the status quo in the US because they believe that elevating the concepts will restrict the FASB in terms of what can be included in the framework if the concepts are to be "applied in practice", (p.47).

Skepticism regarding the Conceptual Framework pre-dated its issuance as FASB Concepts Statement No.1 in 1978 (Cho, Kim and Lim 2010). Such skepticism seems warranted given that the original (and still current) intent of the Conceptual Framework is to guide reasoning in accounting standard setting through a principles-based approach (Storey and Storey 1998: 41-3).

In this paper, we outline further reasons to be skeptical of the likely effectiveness of the FASB's Conceptual Framework. We argue that the Conceptual Framework should be elevated to become the overriding authority within the FASB's 'authoritative' literature. Such 
contention is consistent with McGregor and Street's (2007: 47) view that 'elevating the status of the [conceptual] framework in the US is extremely important.'

Presently, the FASB's Accounting Standards Codification is the single, official source of authoritative, non-governmental GAAP in the United States (U.S.). The formerly multi-level U.S. GAAP hierarchy was compressed to two levels in 2009: authoritative and nonauthoritative. Under this codification, the FASB conceptual framework is considered to fall in the non-authoritative category, whereas more detailed rules, such as those rules related to identifying operating versus capital leases in FASB Statement of Financial Accounting Standard [SFAS] No. 13 (now Codification Topic 840 in FASB 2013), are considered authoritative. Granting 'authoritative' status to the Conceptual Framework would facilitate the transition to a principles-based accounting standards setting environment.

To illustrate our arguments regarding the status of the Conceptual Framework, we review the practices adopted by courts in the U.S. when they consider accounting issues by referring to GAAP and (implicitly at least) the Conceptual Framework. We highlight the rules of evidence that are applied, and draw attention to how the adversarial system of court practice encourages accounting expert witnesses to seek the sanctuary of rules. We are motivated by the '...lack of academic literature that addresses the role of the accountant as expert witness' (Sanchez and Zhang 2012: 103). As well, we are keen to build on the insights provided in this journal to the role of accountants as expert witnesses (Craig and Reddy 2004) and as providers of 'independent expert valuations' (Bugeja 2006).

We draw from the debate over accounting matters that occurred in the criminal trial of Enron's CEO (Jeffrey Skilling) and Chairman (Ken Lay) in 2006. Enron was one of America's major listed companies when it filed for bankruptcy protection in December 2001. The company's collapse prompted considerable negative commentary regarding its financial reporting. Benston and Hartgraves (2002: 126) concluded that US GAAP 'are substantially 
responsible for the Enron accounting debacle'. The inadequacies of Enron's financial reporting triggered criminal charges against Skilling and Lay. Their trial in 2006 offers an opportunity to develop thinking about what is needed for a fairness of presentation reporting framework. A key question considered in the trial, and a motivating research question for this paper, was whether GAAP and the Conceptual Framework dealt adequately with accounting estimates in financial reports.

The status U.S. courts have given to the FASB's GAAP (and thereby to the Conceptual Framework) highlights a paradox (Palmrose 2009). The pervasive protocols applied to assess accounting issues favor a rules-based approach whereas the apparent commitment of the FASB is to adopt a principles-based approach. The adversarial system of U.S. court practice encourages accounting expert witnesses to seek the sanctuary of rules because of a court preference for clear guidelines on what is right and what is wrong. Although an accounting system based on rules might assist in winning a legal battle by invoking GAAP, there is a strong risk that it will fail to meet the needs of financial statement users by distorting any assessment of what constitutes fairly presented financial statements. ${ }^{1}$

Accounting reasoning will cohere better with principles-based accounting if it uses an appropriate Conceptual Framework as the overriding point of reference. ${ }^{2}$ Such use would give priority to substance over form and would be more likely to result in accounting disclosures that are committed strongly to the principle of 'fair presentation'.

The following section briefly reviews two important matters that currently influence assessments of conformity with GAAP in U.S. courts -rules of evidence, and pervading attitudes to expert witness testimony. Thereafter, we evaluate aspects of the accounting reasoning in the trial of Skilling and Lay, particularly in respect of technical conformity with GAAP, and fair presentation. The final section discusses some implications for the evolving Conceptual Framework of financial reporting. 


\section{The U.S. Legal System, Rules of Evidence and Accounting Experts' Testimony}

Some features of U.S. criminal trials

Common law is a distinctive part of the legal system in the U.S.. It is to a system of law based primarily on previous judicial decisions. Unlike statutory law, common law is not codified in statutes via legislation. Thus, a system of law based on common law principles ought to be supportive of principles-based accounting reasoning (Ball 2009: 311). The problems in assessing Enron's accounting appear to have stemmed from the prevalence of a rules-based mentality in the U.S. (Ball 2009: 305). The GAAP hierarchy prevailing at the time of the Enron trial (and in the current FASB codification) was not conducive to GAAP being regarded as a predominantly logic-based reasoning system that arose from a welldeveloped Conceptual Framework.

Juries are used extensively in the U.S. in criminal (and other) trials. They are not required to give reasons for their verdicts, unlike judges. Although judges' instructions can exercise some control over juror deliberations, juries are prone to prejudices and emotional appeals and often fail to comprehend complex issues. Such a perception of jurors is evident in the prosecutor's strategy with respect to the presentation of accounting-based argument in the trial of Skilling and Lay (Hueston, 2007, discussed later).

\section{Rules of evidence}

Skilling and Lay were tried in the United States District Court (Southern District of Texas Houston Division). Evidence presented in this court is regulated by Federal Rules of Evidence [FRE]. These rules seek to ensure the relevance, efficiency, reliability and overall fairness of evidence. There are 68 individual rules, divided into 11 articles. Article 7 deals with 'Opinions and Expert Testimony'. It comprises six rules, numbered 701-706. 
Rule 702, 'Testimony by Expert Witnesses,' clarifies that an expert witness may testify in the form of an opinion or otherwise if:

(a) the expert's scientific, technical, or other specialised knowledge would help the trier of fact to understand the evidence or to determine a fact in issue;

(b) the testimony is based upon sufficient facts or data;

(c) the testimony is the product of reliable principles and methods; and

(d) the expert has reliably applied the principles and methods to the facts of the case.

(Federal Rules of Evidence, Rule 702, available at

http://uscourts.gov/RulesAndPolicies.aspx, last accessed on 4 March, 2013).

Interpretation of Rule 702 has been informed by decisions in two major U.S. cases: (a) Daubert v. Merrell Dow Pharmaceutical Inc, 509 U.S. 579, 113 S. Ct. 2786, 125 L. Ed. 2d 469 (1993); and (b) Kumho Tire Co. v. Carmichael, 526 U.S. 137, 11 S. Ct. 1167, 143 L. Ed. 2d 238 (1999).

In the Daubert case (see also Faigman 1995), the U.S. Supreme Court held that it was not sufficient for expert testimony to be based upon 'general acceptance' in the field to which an expert belongs. Instead, the expert's opinion must be based on 'scientific knowledge.' This implies that such knowledge is acquired from the application of 'scientific method', involving the verification of hypotheses by experimentation and observation. Evidence with this necessary base quality was described by the court as 'reliable.' However, an important question arose as to whether the Daubert principle applied to evidence presented by expert witnesses in fields [like accounting] that were 'non-scientific.' This question was answered in the affirmative in the Kumho case. The Supreme Court concluded that the reliability ruling in Daubert's case applied to all experts, and not just to scientists; and that if an objection was raised, the court must determine whether the evidence presented has 'a reliable basis in the 
knowledge and experience of [the relevant] discipline.' The Kumho case also 'clarified and emphasized that trial judges have flexibility in determining whether an expert's testimony is admissible' (Adrogué and Ratliff 2000: 437). ${ }^{3}$

In the context of the expert accounting evidence in the trial of Skilling and Lay, the unanimous decision of the Texas Supreme Court in Gammill v. Jack Williams Chevrolet Inc., 972 S.W. 2d 713 (Tex. 1998) is instructive. Citing Daubert and Rule 702, the court ruled that expert accounting witnesses should show that the evidence they present is consistent with 'applicable professional standards outside the courtroom.' In the case of accounting, 'professional standards outside the courtroom' were deemed by the U.S. Supreme Court's Advisory Committee on the Federal Rules of Evidence to require the testimony of financial experts to:

... be grounded in an accepted body of learning or experience in the expert's field, and ... explain how the conclusion is grounded. Where the testimony concerns ... accounting standards ... it should be evaluated by reference to the 'knowledge and experience' of that particular field. (Adrogué and Ratliff 2000: 450)

A comprehensive analysis of issues concerning the acceptance of accounting expert testimony by Adrogué and Ratliff (2000: 477-95) concluded that a court's decision on whether to accept evidence of an accounting expert should be informed by six factors. The nature of the accounting expert evidence presented for the defence in the Enron trial rendered only factors 1 to 4 relevant: ${ }^{4}$

1. The accounting profession applies a concept of 'general acceptance' to its 'principles.'

2. The sources of accepted accounting authority are the SEC, FASB, and AICPA.

3. There is a recognised hierarchy of GAAP. 
4. When the underlying subject to which a CPA's testimony relates is based upon a substantive accounting issue, the standards reflected in GAAP may apply, making knowledge of GAAP relevant.

With regard to point 3, Adrogué and Ratliff (2000: 483-4) recommended that courts adopt the AICPA's (1999) 'hierarchy of GAAP for financial statements of non-governmental entities'. This hierarchy (which was still operative at the time of the Enron trial in April and May, 2006) had five strata in descending order of authority. The Conceptual Framework was at the bottom of the hierarchy.

With the issuance of SFAS No. 162 (effective November 13, 2008), 'The Hierarchy of Generally Accepted Accounting Principles', the FASB formalised the lesser importance of Concepts Statements by classifying them as 'other accounting literature.' This literature could be referred to once the levels in the hierarchy had been exhausted (p. 4). SFAS No. 162 was replaced in 2009 by SFAS No. 168, 'The FASB Accounting Standards Codification ${ }^{\circledR}$ and the Hierarchy of Generally Accepted Accounting Principles - a replacement of FASB Statement No. 162.' SFAS 168 (p. 1) noted that 'the GAAP hierarchy will be modified to include only two levels of GAAP: authoritative and non-authoritative.' Since Concepts Statements are not included in the codification, they are non-authoritative; indeed, the FASB asserts on its website: 'A Statement of Financial Accounting Concepts does not establish generally accepted accounting standards.' (http://www.fasb.org/jsp/FASB/Page/SectionPage\&cid=1176156317989). Thus, currently, a hierarchy of two levels of GAAP persists.

Putting a Concepts Statement at the bottom of the hierarchy (as was the case prior to, and including, SFAS No. 162) or establishing a two-tier hierarchy (as SFAS No. 168 did in 2009) suggests that the overriding framework for the FASB's GAAP is based on compliance rather than 'fair presentation.' That is, it does not allow departures and/or disclosures beyond 
specific requirements (for example, of detailed rules). In this regard, it is noteworthy that International Standards on Auditing [ISA] 200 (para 13) makes the difference between a 'fair presentation' framework and a 'compliance' framework clear; and that PCAOB (2003) AU 411 stresses disclosures as the chief means to 'present fairly' in conformity with GAAP. The extent of recourse to the Conceptual Framework for deliberative support should be an important consideration for courts when assessing any expert accounting evidence.

\section{Expert witness evidence}

Accountants have a long tradition of providing expert witness evidence in a variety of judicial settings throughout the world. They are also called upon to provide expert opinion in many non-judicial or quasi-judicial contexts, such as in providing valuation reports in connection with takeover bids, schemes of arrangement, and acquisitions or buy-outs.

In the U.S., court proceedings are inherently adversarial. The parties call expert witnesses specifically to buttress their cases. In the Enron case, the accounting expert witnesses testified that Enron's financial reports fully conformed to GAAP. Expert witnesses in U.S. courts are not bound by any overarching obligation to be a 'pure' expert disassociated from the parties. Thus, the hostile questioning which often arises is directed not so much to evince the truth, but rather to damage the professional credibility of the other party's expert witness.

Ideally, an expert witness's evidence should appeal extensively because of its logic, rather than because of the credibility of the witnesses or the strength of emotional appeals. Otherwise, it risks becoming 'emotional, imprecise and open to interpretation' (Norreklit 2003: 595). Because arguments usually draw strength from the credibility of the provider, maintaining the reputation of an expert witness explains why much trial questioning in the 
U.S. focuses on enhancing (or attacking) the credibility of the expert witness, rather than addressing the issue under consideration.

U.S. courts have had a long held 'frustration about experts for hire' (Adrogué and Ratliff 2000: 435). This concern is echoed by the Australian Securities and Investments Commission in its Regulatory Guide 112 (Independence of Experts, issued March 2011. Retrieved on 22 August 2013 from http://www.asic.gov.au/asic/pdflib.nsf/LookupByFileName/rg11230032011.pdf/\$file/rg112-30032011.pdf). This guide states that 'An expert's opinion that is tailored to support the views of the commissioning party or any other interested party is not a genuine opinion.' (RG 112.16).

Anyone reflecting upon the expert evidence provided by accountants should be mindful that objectivity is a fundamental guiding principle of accounting. This guiding principle should be juxtaposed against judicial concerns regarding the 'inadequate objectivity' and the 'perceived lack of independence' often provided in the expert evidence of accountants (Freckelton et al. 1999: 3, 13). A strong case emerges 'for renewed commitment by accountants to the fundamental ethical principles of professional endeavour ... [and for them to]... commit themselves more vigorously to helping the courts in their "search for truth ... [un]affected by any of the sordid concerns of commerce or the emotions which affect ordinary human beings"' (Craig and Reddy 2004: 77, citing Chesterman 2000: 13). It should be noted that accountants' rules of professional ethics are principles-based and so can provide a consistent foundation from which to develop principles-based accounting.

Consideration should be given to changing the obligations of expert witnesses in the U.S. to one that is held in some non-U.S. jurisdictions such as Australia: specifically, that expert witnesses have an overriding duty to assist a court, to be objective, and not be advocates for any party (Federal Court of Australia 2012). The role of expert witnesses is to help the court understand a complex technical matter requiring non-legal professional 
expertise. Any tendency to be partisan is ameliorated by the requirement for experts to declare, at the end of their report, that '[the expert] has made all the inquiries that [the expert] believes are desirable and appropriate and that no matters of significance that [the expert] regards as relevant have, to [the expert's] knowledge, been withheld from the Court' (para 2.3).

In non-judicial contexts, the apparent lack of independence and objectivity of some Australian accountant experts was highlighted by Bugeja (2006) in respect of expert reports produced by a target [firm's] auditors in takeovers in Australia between 1990 and 2000. His results 'suggest a perceived lack of independence of expert reports ... lead[ing] to the share market viewing those reports as being less than credible' (Bugeja 2006: 20).

Clearly, there is an 'obvious tension' to be resolved 'between the judicial desire for a 'pure' expert and the reality of litigation conducted by adversaries' (Chesterman, 2000: 14). The 'pure expert' is encountered rarely in U.S. judicial settings. American courts do not dwell on the nostalgic fondness of legal reformers for 'an Aristotelian "ideal expert witness"” (Chesterman 2000: 13). Nonetheless, adoption of a 'pure expert' mentality would be consistent with a principles-based approach to accounting.

\section{GAAP in the Enron Criminal Trial}

In his opening address to the jury, the lead litigator for the prosecution, John Hueston, framed the case in such a way that mere compliance with (technical) accounting standards would not excuse the defendants' 'choices.' He claimed these choices had resulted in 'lie after lie about the true financial condition of Enron' (Hueston 2007: 207). A good part of the prosecution's strategy was directed to convincing the jury that compliance with GAAP was no absolution from criminality.

Whether the prosecution's strategy influenced the final verdict is not germane here. We are not concerned about legal tactics generally, but about the potential for GAAP to facilitate 
corporate fraud by condoning inapt financial reporting - implicitly or otherwise. Thus, we highlight the defence's reliance on the evidence of two accounting expert witnesses (both prominent members of the American accounting profession), Jerry Arnold and Walter Rush. They testified that Enron's accounting complied fully with GAAP. Despite this supportive expert testimony, Lay and Skilling were convicted on May 25, 2006 of (among other charges) conspiracy to commit securities fraud; and Skilling was convicted also of committing securities fraud.

The convictions arose from matters related to Enron's quarterly financial statements. The guilty judgments invite a conclusion that Enron's financial reporting was not in conformity with GAAP. However, such a conclusion is precipitate because, in three days of testimony, the two expert witnesses argued that Enron's accounting fully conformed to GAAP. Thus, ostensible mere compliance with GAAP by Enron appeared not to have impressed the jury. This has stimulated our interest in exploring the implications of arguments regarding GAAP compliance for the GAAP hierarchy - including in the context of the more recent two-tier hierarchy.

There is an important distinction between financial reporting frameworks based on compliance and those based on fair presentation. A compliance framework is rules-based, whereas a fairness of presentation framework justifies departures from the rules, or disclosures beyond rule requirements, and is principles-based. The fair presentation framework has been revised in ISAs 200, 210, and 700 by the IAASB in its 'Clarity Project' (www.iaasb.org). The evolving audit principles embodied in those revisions need to be better integrated with the IASB/FASB's (2010) joint accounting conceptual framework project. Further evidence of this need is provided by Christensen et al.'s (2012) concerns that accounting estimates have extreme estimation uncertainties (specifically, uncertainties about 
what IAS 540 refers to as 'judgmental misstatements'). Benston $(2006 ; 2008)$ outlined similar concerns regarding Enron's accounting.

\section{Discussion}

The two expert witnesses testified that Enron's accounting conformed to GAAP. Even if their argument is true, and Enron's accounting was technically in conformity with GAAP, is GAAP a necessary but insufficient condition to indicate fair presentation? (Alexander and Archer 2003; Zeff 2007; Mano et al. 2009; Palmose 2009). If so, what would have been the features of the accounting required to result in fair presentation? Although we agree that Enron's accounting can be considered to have conformed to GAAP, we do not agree that Enron's accounting constituted fair presentation. There seems to be a clear need to address important deficiencies in GAAP in a revised Conceptual Framework, including the ethical principles that underpin the framework (Smieliauskas 2013).

To develop logically appropriate set of principles, a Conceptual Framework should have primacy within the GAAP hierarchy. For example, the principles based reporting framework of the Institute of Chartered Accountants of Scotland (ICAS 2006) requires a clear hierarchy of overriding concepts that meet the public interest. A good example of principles-based reasoning in existing professional standards is IFAC's Code of Ethics for public accountants.

A detailed rule should not conflict with a basic principle. If it did, the resulting system of ethical reasoning could be shown to be illogical (i.e., inconsistent) and rejected in a trial. Detailed rules should clarify the application of a principle in a particular context, yet be consistent with it. A principle has conceptual primacy over a detailed rule. This means that if a rule conflicts with a principle in a given context, the principle overrides the rule. Principlesbased reasoning has always been important in moral philosophy and the study of logic (see Smieliauskas 2013). 
The focus of the expert witnesses on technical conformity with accounting rules rather than on the actual intentions of the defendants was logical in an environment where rules are presumed to dominate over broader principles. However, in a well-developed principlesbased system, users should not be misled. What is misleading, for whom, and the need to give priority to user needs, are essentially ethical issues for a particular reporting environment. Fair presentation should be based on ethical reporting principles. Thus, the objectives and related concepts and principles inherent in the Conceptual Framework should be located at the top, rather than at the bottom, of the GAAP hierarchy. They should be the foundation of the framework of codification. Detailed rules should then logically follow (and be derived from) the general principles and assumptions. The result would be a more coherent system: one that is easier to defend logically in a court of law. For example, as Cho et al. (2010) note, appropriately developed concepts such as relevance and reliability (faithful representation) in a Conceptual Framework can provide the basis for appropriate implementation of more detailed rules.

A revised GAAP hierarchy/codification (with improved concepts and a stronger focus on objectives of financial reporting grounded in a theory of ethical reporting) can promote wider acceptance of the 'fair presentation' concept in financial reporting. The need to satisfy the objectives of financial reporting should be installed as the broadest generalisation in the GAAP hierarchy. In the interests of strengthening the logic of accounting argumentation (e.g., in courts), detailed accounting standards and rules should be consistent with the Conceptual Framework. In specific circumstances when they are not, then the rules should be overridden by the overall objectives of the Conceptual Framework. Failure of standard-setters to develop such a system (for example, in FASB No. 162 and in SFAS No. 168) will prevent GAAP from becoming more ethical and more logical. 


\section{References}

Adrogué, S. and Ratliff, A. 2000, 'Kicking the tires after Kumho: The bottom line on admitting financial expert testimony', Houston Law Review, 37 (2): 431-514.

American Institute of Certified Public Accountants (AICPA) 1999, 'The Meaning of Present Fairly in Conformity with Generally Accepted Accounting Principles in the Independent Auditor's Report' in Codifications on Accounting Standards, AU §411.10-.11:389-90. Alexander, D. and Archer, S. 2003, 'On economic reality, representational faithfulness and the "true and fair override", Accounting and Business Research, 33 (1): 3-17.

Ball, R. 2009, 'Market and political/regulatory perspectives on the recent accounting scandals', Journal of Accounting Research, 47 (2): 277-323.

Benston, G.J. 2006, 'Fair-value accounting: A cautionary tale from Enron', Journal of Accounting and Public Policy, 25 (4): 465-484.

Benston G.J. 2008, 'The shortcomings of fair-value accounting described in SFAS 157', Journal of Accounting and Public Policy, 27 (2): 101-114.

Benston, G.J. and Hartgraves, A.L. 2002, 'Enron: What happened and what we can learn from it?' Journal of Accounting and Public Policy, 21 (2): 105-127.

Bugeja, M. 2006, 'Independent expert valuations in takeovers: Are they biased?' Asutralian Accounting Review, 16 (2): 19-24.

Chesterman, R.N. 2000, 'The accountant as expert witness'. Paper presented to the Institute of Chartered Accountants in Australia, Sydney, 12 March. Available athttp://archive.sclqld.org.au/judgepub/2001/CH_Dealing\%20with\%20Expert\%20Witnesses. pdf last accessed on 7 June 2013.

Christensen, B.E., Glover, S.M. and Wood, D.A. 2012, 'Extreme estimation uncertainty in fair value estimates: Implications for audit assurance', Auditing: A Journal of Practice \& Theory, 31 (1): 127-146. 
Cho, M., Kim, O. and Lim, S.C. 2010, 'Two conflicting definitions of relevance in the FASB Conceptual Framework', Journal of Accounting and Public Policy, 29: 604-611.

Craig, R. and Reddy, P. 2004, 'Assessments of the expert evidence of accountants', Australian Accounting Review, 14 (1): 73-80.

Dunfee, T.W. 1970, 'Professional criminal liability: United States v. Simon', American Business Law Journal, 8 (3): 315-319.

Faigman, D.L. 1995, 'The evidentiary status of social science under Daubert: Is it "scientific", "technical", or "other" knowledge?' Psychology, Public Policy, and Law, 1(4):960-979. Federal Court of Australia 2012, 'Expert Witnesses in Proceedings in the Federal Court of Australia', Practice Note CM 7, available at www.fedcourt.gov.au, last accessed 6 June 2012. Financial Accounting Standards Board (FASB) 2009, The Hierarchy of Generally Accepted Accounting Principles, Exposure Draft. Available at http://www.fasb.org/draft/ed_amendment_fas162.pdf last accessed 8 November 2010 Financial Accounting Standards Board (FASB) 2010, Conceptual Framework for Financial Reporting, FASB, Norwalk, CONN..

Freckelton, I., Reddy, P. and Selby, H. 1999, Australian Judicial Perspectives on Expert Evidence: An Empirical Study, Australian Institute of Judicial Administration, Melbourne. Hueston, J.C. 2007, 'Behind the scenes of the Enron trial: Creating the decisive moments', American Criminal Law Review, 44 (2):197-239. International Standards on Auditing (ISA) 2011, Overall objectives of the independent auditor and the conduct of an audit in accordance with International Standards on Auditing. International Federation of Accountants Handbook, Ethics and International Standards on Auditing.

International Accounting Standards Board (IASB) 2010, Conceptual Framework for Financial Reporting under International Financial Reporting Standards (IFRS), Available at 
http://www.ifrs.org/NR/rdonlyres/6A6ABF86-D554-4A77-9A4A-

E415E09726B6/0/CFFeedbackStmt.pdf, last accessed 7 November 2010.

Mano, R.M., Moritsen, M. and Pace, R. 2006, 'Principles-based accounting', CPA Journal, February: 60-63.

McGregor, W. and Street, D. L. 2007, 'IASB and FASB face challenges in pursuit of joint conceptual framework,' Journal of International Financial Management and Accounting, 18 (1): 39-51.

Norreklit, H. 2003, 'The balanced scorecard: What is the score? A rhetorical analysis of the balanced scorecard', Accounting, Organizations and Society, 28 (6): 591-619.

Palmrose, Z-V. 2009, 'Science, politics, and accounting: A view from the Potomac', Accounting Review, 84 (2): 281-297.

PricewaterhouseCoopers 2011, Daubert Challenges to Financial Experts: An 11-year Study of Trends and Outcomes. Available at http://www.pwc.com/us/en/forensicservices/publications/daubert-study-2010.jhtml last accessed 7 June 2013. Public Company Accounting Oversight Board (PCAOB) 2010, FASB/IASB Projects and Potential Challenges to Auditing. PCAOB Standing Advisory Group Meeting Document: October 13-14. Washington, DC.

Public Company Accounting Oversight Board (PCAOB) 2003, Interim Standard AU 328: Auditing Fair Value Measurements and Disclosures. Available at www.pcaobus.org last accessed 7 June 2013.

Public Company Accounting Oversight Board (PCAOB) 2003, Interim Standard AU 411: The Meaning of Present Fairly in Conformity with Generally Accepted Accounting Principles. Available at www.pcaobus.org last accessed 7 June 2013.

Sanchez, M.H. and Zhang, S.W. 2012, 'The role of the expert witness in accounting fraud cases', Global Journal of Business Research, 6 (1):103-111. 
Smieliauskas, W. and Bewley, K. 2013, Auditing: An International Approach, McGraw-Hill Ryerson, Toronto, Ontario.

Smieliauskas, W. 2013, 'Argument, audit and principles based accounting estimates', in Jack, L., Davison, J. and Craig, R. (eds), 2013, The Routledge Companion to Accounting Communication, Routledge, London, UK: 228-241.

Storey, R.K. and Storey, S.S. 1998, The Framework of Financial Accounting Concepts and Standards, Financial Accounting Standards Board, Norwalk, CONN..

Zeff, S.A. 2007, 'The primacy of "presents fairly” in the auditor's report', Accounting Perspectives, 6 (1): 1-20.

\section{Notes}

${ }^{1}$ A notable exception is the court decision in the Continental Vending Case [United States vs. Simon, 425 F.2d 796 (2d Cir. 1969)]. This set a court precedent concerning the meaning of fair presentation in financial reporting (see Mano et al. 2006; Dunfee, 1970).

${ }^{2}$ This is the logic of the argumentation process used to support decisions in professional ethics reasoning (e.g., see Smieliauskas and Bewley 2013; Palmrose 2009).

${ }^{3}$ PricewaterhouseCoopers (2011) documents trends in Daubert challenges since the Kumho Tire decision. In 2010, in American Honda Motor. Inc. v. Allen, the Seventh Circuit held that district courts 'must perform a full Daubert analysis' in class actions (PricewaterhouseCoopers 2011: 5).

\footnotetext{
${ }^{4}$ Points 5 and 6 are:
} 
5. In other cases, GAAP is not strictly applicable to the services provided by the CPA. Instead, GAAP provides guidance as to accepted accounting practices and procedures, and various AICPA technical guides suggest accepted methodologies.

6. When the CPA is applying methodologies from other disciplines, both the standards of the other discipline, and accounting standards, may apply.

Points 5 and 6 were redundant in the Enron case because there was a substantive issue underlying the accountants' testimony; and because there was no recourse in the testimony to methodologies from non-accounting disciplines. Therefore, the acceptability of the experts' evidence was assessed by recourse to points 1 to 4 alone (an evaluative framework of GAAP). 